\title{
Économie des institutions, de l'innovation et de la croissance
}

Philippe Aghion

\section{(2) OpenEdition \\ Journals}

Édition électronique

URL : https://journals.openedition.org/annuaire-cdf/15674

DOI : 10.4000/annuaire-cdf. 15674

ISBN : 978-2-7226-0572-5

ISSN : 2109-9227

Éditeur

Collège de France

Édition imprimée

Date de publication : 30 décembre 2020

Pagination : 491-493

ISBN : 978-2-7226-0516-9

ISSN : 0069-5580

\section{Référence électronique}

Philippe Aghion, "Économie des institutions, de l'innovation et de la croissance », L'annuaire du Collège de France [En ligne], 118 | 2020, mis en ligne le 01 avril 2021, consulté le 22 août 2022. URL : http:// journals.openedition.org/annuaire-cdf/15674; DOI : https://doi.org/10.4000/annuaire-cdf.15674 


\title{
ÉCONOMIE DES INSTITUTIONS, DE L'INNOVATION ET DE LA CROISSANCE
}

\author{
Philippe AGHION \\ Professeur au Collège de France
}

Mots-clés : économie, institutions, innovation, croissance, entreprises, réallocation, dynamique, productivité

La série de cours «Croissance, réallocation et dynamique des entreprises » est disponible, en audio et en vidéo, sur le site internet du Collège de France (https:// www.college-de-france.fr/site/philippe-aghion/course-2017-2018.htm).

\section{ENSEIGNEMENT}

COURS - CROISSANCE, RÉALLOCATION ET DYNAMIQUE DES ENTREPRISES

\section{Cours 1 - Croissance schumpétérienne et dynamique des firmes}

1. Introduction

2. Qui créé le plus d'emplois et qui contribue davantage à la croissance de la productivité ?

3. Ce qui favorise ou contraint la croissance des entreprises

\section{Cours 2 - Productivité et dynamique des entreprises en comparaisons internationales}

1. Misallocation et productivité en comparaison États-Unis/Inde/Mexique

2. Comparaisons internationales de dynamique des firmes et productivité

3. Management et richesse des nations

\section{Cours 3 - Dynamique des entreprises et mesure de la croissance}

1. Mesure de la croissance : présentation générale

2. Croissance manquante et destruction créatrice 


\section{Cours 4 - Politique industrielle et rôle de la sélection dans la dynamique des firmes}

1. Sélection et délégation, le cas indien

2. Entreprises familiales dans les pays en développement

3. Politique industrielle

4. Connexions politiques, innovation et dynamique des firmes

\section{Cours 5 - Automatisation et intelligence artificielle}

1. Intelligence artificielle

2. Impact de la robotisation sur le marché du travail

3. Robotisation et démographie

4. Innovation, firmes et inégalités salariales

\section{Cours 6 - Croissance et évolutions structurelles}

1. De la stagnation à la croissance

2. Kaldor facts

3. Modéliser le changement structurel

\section{Cours 7 - Le retour de la rente ?}

1. Le retour de la rente?

2. Exports et innovation

\section{COLLOQUE - TRADE AND INNOVATION}

Cette journée de conférences, organisée par Philippe Aghion et Margaret Kyle, s'est déroulée le 15 décembre 2017 au Collège de France :

- «Tarif reductions, entry and welfare: theory and evidence for the last two decades », John Romalis (University of Sydney, Australia) ;

- «Exports and innovation: theory and evidence », Philippe Aghion (Collège de France, PSE et LSE);

- «Escaping the competition: the impact of China's exports on chinese and global innovation », Kevin Lim (University of Toronto, Canada) ;

- «Does offshoring manufacturing harm innovation in the home country? Evidence from Taiwan and China », Lee Branstetter (Carnegie Mellon, États-Unis);

- «Connecting to power: political connections, innovation, and firm dynamics », Salome Baslandze (Einaudi Institute for Economics and Finance, Italie);

- «Patent exhaustion regime and international production sharing winners and losers? », Olena Ivus (Queen's University, Canada);

- «Effects of copyright on science », Petra Moser (New York University, États-Unis) ;

- «Intellectual property reform, exports and productivity of heterogeneous firms in developing countries: evidence from China », Keith Maskus (University of Colorado, États-Unis) ;

- «Intellectual property rights and access to innovation: evidence from TRIPS », Margaret Kyle (Mines ParisTech, France) ;

- «Patents, trade, and foreign direct investment in the European Union », Yann Meniere (European Patent Office). 


\section{COLLOQUE - MARKET POWER, TECHNOLOGY AND PRODUCTIVITY}

Ce colloque, organisé par Philippe Aghion, Giammario Impullitti et Ufuk Akcigit, s'est déroulé les 12 et 13 juin 2018 au Collège de France :

- «The rise of market power and the macroeconomic implications », Jan De Loecker ;

- «Declining competition and investment in the US », German Guitterez ;

- «The rise of monopoly power in the US », Jacob Robbins ;

- «Technology, market structure and the gains from trade », Giammario Impullitti ;

- «Dancing with the stars: innovation through interactions », Ufuk Akcigit ;

- «Labor supply in the past, present, and future: who and how much?», Timo Boppart ;

- «Optimal taxation and endogenous productivity », Xavier Jaravel ;

- «Connection to power: political connections, innovation, and firm dynamics », Salomé Baslandze ;

- «The spillover effects of top income inequality», David Hemous (w/ Jeff Clemens, Josh Gottlieb et Morten Olsen);

- «Productivity and misallocation in general equilibrium », Emmanuel Farhi ;

- «The returns to invention », Philippe Aghion.

\section{Publications}

Aghion P., Bergeaud A., Lequien M. et Melitz M., « The impact of exports on innovation: theory and evidence $», 2017$.

Aghion P., Akcigit U., Lequien M. et Stantcheva S., « Do entrepreneurship and selfemployment respond to simpler fiscal incentives? Evidence from France », 2017.

Aghion P., Akcigit U., Lequien M. et Stantcheva S., « Does self-employment respond to simpler fiscal incentives? Evidence from France », 2017.

Aghion P., Akcigit U., Hyytinen A. et Toivanen O., «Living the American dream in Finland: The social mobility of inventors », 2017.

Aghion P. et Antonin C., «Progrès technique et croissance depuis la crise », Revue de l'OFCE, no 153,2017 , p. 63-78.

Aghion P., Bergeaud A., Blundell R. et GrifFith R., «Innovation, firms and wage inequality », 2017.

Aghion P., Bergeaud A., Boppart T., Klenow P. et Li H., « Missing growth from creative destruction », Working Paper, Londres, Centre for Economic Performance, LSE, 2017.

Aghion P., Bloom N., Lucking B., SAdun R. et ReEnen J.V., Turbulence, Firm Decentralization and Growth in Bad Times, Working Paper, Cambridge, MA, National Bureau of Economic Research, 2017.

Aghion P., BergeAud A., LeQuiEn M. et Melitz M.J., The Impact of Exports on Innovation : Theory and Evidence, Working Paper, Paris, Banque de France, coll. «Working Paper Series », 2018 ; Working Paper, Cambridge, National Bureau of Economic Research, 2018, DOI : $10.3386 / \mathrm{w} 24600$.

Aghion P., Fehr E., Holden R. et Wilkening T., « The role of bounded rationality and imperfect information in subgame perfect implementation: An empirical investigation », Journal of the European Economic Association, vol. 16, nº 1, 2018, p. 232-274, DOI : 10.1093/ jeea/jvx026. 
